morality; for it is well known that the bulk of the crime of this country is caused by drink.

That it was much needed a very superficial observation of the condition of certain quarters of towns on Saturday night is of itself sufficient to prove. And even in the country the great number of public houses and the great number of people frequenting them are very noticeable.

The police have taken up the matter rigorously, and they will no doubt be supported and encouraged by Magistrates and Justices of the Peace. Apart from questions of public decency and morality, the medical profession will welcome any reform in respect of drunkenness warmly, knowing well how largely the excessive consumption of alcohol is responsible directly and indirectly for disease, poverty, physical degradation and death.

\section{The Use of Paraffin in Surgery}

The injection of paraffin into the tissues has become an established procedure in surgery. The use of the material for raising sunken noses and correcting facial deformities of sort has imparted to the process a sensational character; but it was originally introduced by Gersuny of Vienna for quite different purposes, and is still resorted to for the cure or relief of prolapse, fistula, hernia, etc. A most interesting history of the subject with illustrations of the uses and benefits of paraffin injections is given by Mr. Steven Paget, F.R.C.S., in a lecture published in the British Medical Journal for 3rd January. How far the process is practicable in the tropics remains to be seen. High febrile atmospheric and solar temperatures are hostile to it, and if used at all, a paraffin of high melting point must obviously be employed.

\section{Another Prize Day at Netley}

Netley still survives. Twenty-nine lieutenants-on-probation as they are now called, belonging to the Indian Medical Service, underwent a two months' course of instruction in military medicine and surgery, refraction, $\mathrm{X}$-rays and lunacy, and prizes were publicly distributed to the successful examinees on the 10th of January by Sir William Roe Hooper, K.C.S.I., who delivered a most excellent address on the occasion. He announced that until suitable arrangements are made elsewhere for the more practical parts of the course of instruction included in the programme of the Medical Staff College, junior officers of the Indian Medical Service will continue to come to Netley, which has been taken for purposes of teaching and training under the direct control of the Advisory Board. The Indian Medical Service retains its popularity. Forty-one highly qualified candidates have entered the competition for thirteen advertised appointments.

\section{$M r$. Johnathan Hutchinson's Visit to India}

Mr. Johnathan Hutchinson has gone to India for the purpose of making enquiries regarding his pet subject of leprosy and obtaining evidence in support of his pet theory of the fishcausation of that disease. Indian medical officers must, therefore, be prepared to supply him with information, and I hope that on the principle of audi alteram partem data will be furnished against as well as for the hypothesis which he holds as a fixed belief.

\section{K. McL.}

15th January, 1903.

\section{ERRATUM}

\section{INDIAN MEDICAL GAZETTE \\ Fifty Years Ago}

In the January number, on Page 52, Col. 1, the signature should be in the next para, between the $3 \mathrm{rd}$ and the 4 th lines as in the original communication, 50 Years ago.

\section{Medical News}

\section{'D.T.M. EXAMINATION'}

OwIng to affiliation of the D.T.M. course to the Calcutta University from 1953-54 session, a D.T.M. examination under the Faculty of Tropical Medicine and Hygiene will, for the last time, be held about the end of September 1953. Students who failed or did not appear in the examinations since 1950-51 are eligible for this examination. A refresher course for students will commence from 17th August 1953. For particulars apply at once to the Director, School of Tropical Medicine, Calcutta.

\section{ENCOURAGING RESULTS REPORTED IN THE FIGHT AGAINST YAWS \\ *By R. R. WILLCOX, m.D. \\ London}

(Reproduced from a Press Release No. ROA/PR 004, dated 3rd March, 1953, issued by Pan-American Sanitary Bureau Regional Office, World Health Organization, 1501, New Hampshire Avenue, N.W., Washington 6, D.C., Hudson 3-5280)

Yaws begins as a small inisignificant sore usually on the foot or leg, a sore which grows, and as the disease develops fresh sores break out anew elsewhere. The disease attacks the bones and eats away the tissues like termites, undermining the strongest physiques. The face may lose all human aspect and 'become nothing more than a night-marish mask worthy of the legends of the Middle Ages. 
These are the effects of yaws (also known as framboesia). which ravages the tropical regions of Africa, America, Oceania and Asia.

Particularly interesting revelations were made during a conference organized at Bangkok by the World Health Organization in collaboration with the Government of Thailand. The conference was attended by UNICEF representatives and outstanding specialists in yaws and treponemal diseases.

\section{What is yaws?}

The contagious disease of yaws has for a long time been confused with syphilis. Both diseases are caused by identical micro-organisms, or treponemes, i.e. $T$. pallidum in the case of syphilis and T. pertenue in that of yaws. Bejel, another treponemal disease, is prevalent above all in the Eastern Mediterranean area. The climate most favourable to yaws is a humid tropical one, where intense heat alternating with heavy rain, falls on a soil which is not very porous and gives rise to a luxuriant vegetation. It has been found that yaws tends to decrease during the dry season and to increase during the wet season. Primarily a rural disease, yaws is tarnsmitted by human contact as well as by contact with dirty linen or clothing and other articles of everyday use. No decision has yet been reached as to whether insects act as vectors of the disease (flies, mosquitoes, etc.).

Undernourished individuals living in overpopulated areas are much more receptive than others. Peasants who move about barefoot in tropical countries are prone to develop foot lesions; the same phenomenon being noted amongst soldiers during the recond world war.

It is extremely difficult to discover, before the characteristic lesions appear, whether a patient is suffering from syphilis or from yaws. Yaws itself is not hereditary, but a child born healthy to infected parents will in turn be infected by contact with them during infancy.

\section{The fight against superstition}

One of the main obstacles confronting doctors combating the disease is superstition. In fact, in some regions there is a popular belief that the men will not be strong and able to face life successfully unless they have contracted some very spectacular form of yaws.

Not only do those infected adopt completely inadequate measures to check the disease (e.g. by swallowing a decoction made from snakes with a skin showing patterns similar to those left by yaws on the human skin), but children may even be deliberately infected from earliest youth, with the possible resultant mutilation of their bodies by the age of 12 .

\section{Yaws can be conquered}

In the impressive Sahathai Hall of the grand palace of Bangkok, with its apparently jewel-encrusted prangs pointing to the sky, the King of Thailand had put several rooms at the disposal of those attending the conference. There, shirt-sleeved doctors, selected experts from all over the world, compared the results obtained in the control of yaws by the different international teams, including those of W.H.O.

The conviction rapidly grew that yaws could be definitely cured by giving the patients one, or at the most two or three intramuscular injections of repository penicillin at intervals of a few days. No tendency of the treponeme to develop resistance was noted.

Such treatment has proved more effective, less dangerous, cheaper and more manageable than all treatment with orally administered antibiotics, which must be persevered with for a longer time by patients who, despite the serious nature of the disease, often tend to forget medical advice all too quickly.

It should be noted that the majority of patients prefer to undergo injections, sometimes painful ones, rather than swallow other remedies, such as pills, etc. perhaps in accordance with the theory that "something that doesn't hurt cannot do any good'.

Up to 31st December, 1952, nearly 8 million persons had been examined in Haiti, Indonesia, Thailand and the Philippines, during the large-scale campaigns against yaws undertaken with the assistance of W.H.O.; some 3 million were found affected and have been treated.

$\begin{array}{llccr} & & & \text { Examined } & \text { Treated } \\ \text { Haiti } & . & \ldots & . . & 2,270,051 \\ \text { Indonesia } & . & \ldots & 3,529,831 & 553,587 \\ \text { Thailand } & . & \ldots & 1,679,342 & 216,047 \\ \text { Philippines } & . & \ldots & 415,000 & 24,000\end{array}$

It has been calculated that the cost of the treatment given, including expenditure on staff and material, amounts to less than 3 dollars per capita. Thus only 3 dollars may be the price of health and vigour in countries where the community needs an everincreasing number of workers to improve its lot.

* Dr. Richard Robert Willcox, of London, M.R.C.S., L.R.C.P., formerly a consultant to the World Health Organization for the Eastern Mediterranean area, is a member of several scientific societies. He is at present consultant to the V.D. Department of St. Mary's Hospital, London, and King Edward VII Hospital, Windsor.

\section{DRUG RULES, 1945}

(No. F.1-4/51-DS., Government of India, Ministry of

Health, New Delhi-2, the 18th February, 1953)

\section{NOTIFICATION}

THE following draft of certain further amendments in the Drugs Rules, 1945, which it is proposed to make in exercise of the powers conferred by sections 12 and 33 of the Drugs Act, 1940 (XXIII of 1940), is published as required by the said sections for the information of all persons likely to be affected thereby and notice is hereby given that the draft will be taken into consideration on or after the 21st May, 1953.

2. Any objection or suggestion which may be received from any person with respect to the said draft before the date specified will be considered by the Central Government.

\section{Draft Amendments}

In the said Rules-

1. To rule 18 , the following proviso shall be added, namely :-

'Provided that if the applicant fails to apply for renewal of a certificate of registration before the expiry of the certificate in force the few payable for the certificate of renewal of registration shall be hundred rupees.'

2. To sub-rule (1) of rule 69 , the following proviso shall be added, namely :-

'Provided that if the applicant fails to apply for renewal of licence before the expiry of the licence in force, the fee payable for the renewal of the licence shall be rupees forty.' 
3. To sub-rule (1) of rule 75 , the following proviso shall be added namely :-

'Provided that if the applicant fail/s to apply for renewal of licence before the expiry of the licence in force, the fee payable for the renewal shall be rupees forty.'

\section{Sd./- S. DEVANATH,} Under Secretary.

\section{DR. DHIRAJRAI MATHURANDAS VASAVADA}

\section{To the Editor, 'Indian Medical GazeTte', Calcutta}

DeAr Sir,-We regret to report the death of Dr. Dhirajrai Mathurandas Vasavada, which took place at Junagadh (Saurashtra) on 21st December, 1952. The late Dr. D. M. Vasavada was attached to the Miraj Medical Centre from 1915-1918 and was Senior Assistant Surgeon at State Hospital, Bikaner (19191930). He had been practising at Junagadh since 1931, till time of his death. He was a keen advocate of intravenous therapy and edited Journal of Intravenous Medication published in 1931.

Yours faithfully,

A. D. VASAVADA, м.B.B.S.

BAZAR FALia, JunAGadH

(SAURASHTRA),

28th March, 1953.

(Reproduced from Release No. B.F. 408, issued by the British Information Services, New Delhi)

\section{WORK OF INDIAN FIELD AMBULANCE IN KOREA}

\section{SECRET of Unit's PopUlarity}

By G. D'Arnaud-Taylor

\section{Writing from Korea}

THE youngest and oldest Commanding Officer in the Commonwealth Division is leaving Korea for home. Both these titles are borne by one man-Lt.-Col. A. G. Rangaraj, м.v.c., of Vellore, South India. For 'Range', as he is affectionately known to the officers of the Division in Korea, is only 33 years of age.

Col. Rangaraj arrived in Korea with his unit, the 60th Indian Field Ambulance, in November 1950. His is the only unit to serve three winters in Korea and he has been with his men throughout. Now 'Range' is in process of handing over to his relief, Lt.-Col. M. S. K. Nair, M.c., of Tellicherry, an officer with a long record of gallantry in the Western Desert and in Italy.

When Col. Rangaraj took his unit to Korea it consisted of 331 officers and men, everyone of whomfrom the Commanding Officer down to the noncombatant sweepers-was a paratrooper. Of the original 331,188 are still serving and 50 per cent of the replacements are also qualified to wear the red beret. Not long after his arrival, Col. Rangaraj found that his was the only medical unit in Korea qualified to take part in an airborne landing, and readily offered his services when asked to provide an airborne surgical team to accompany the 187 U.S. Paratroop Regiment in an action early in 1951 .

On the formation of the Commonwealth Division in June 1951, the 60th Indian Field Ambulance became part of the 28th Brigade, with its British and Australian troops and its New Zealand gunners, thuis giving the 28th a completely Commonwealth complexion.
From the time it joined te Brigade until the Division was withdrawn from the frontline for the first time in January this year, the Indian unit has treated 1,400 battle casualties and 9,000 sick and wounded. These figures do not include the average of 20 daily who are treated by the unit's dental officer (Captain B. Sur of Delhi) or as out-patients for routine day-to-day ailments.

\section{South Koreans trained}

Not all the unit has been in the frontline at any one time. A detachment has been in Taegu since mid1951, where it has worked with the United Nations Korea Rehabilitation Agency in reorganizing the South Korean civilian and military hospitals in the area. Perhaps the greatest accomplishment of the detachment-the personnel are constantly being interchanged with these of the main unit at the front-is in the training of South Korean anæsthetists. Over 205 fullyqualified anæsthetists have been turned out at Taegu and despatched throughout South Korea to pass on the instructions so eagerly acquired from the Indian doctors.

The Indian Field Ambulance is unique in another respect. It is the only unit in the Commonwealth Division to be completely supplied from its own country. It arrived in Korea fully equipped with vehicles and tents, medical, surgical and dental instruments, drugs, medicines and bandages, etc. Any replacements, except for expendable drugs which are supplied by Britain, also come from India.

The bulk of the unit's rations are also shipped from India. From there come all the condiments, atta, dhal and ghee. Fresh meat and vegetables are the only items supplied through British services and these are paid for by the Government of India. This has enabled the Field Ambulance personnel to continue to have the food to which they are accustomed and at the same time has made the Field Ambulance a port of call for many who like a good curry.

\section{'Perfection of cleanliness'}

Hospitality and charm are combined in all the occupants of the officers' mess, where rarely a mealtime passes without someone dropping in 'for pot luck'. British officers with their long association with India, are the greatest curry enthusiasts, with the Australians next and the Canadians and Americans tying for third place.

Many, too, go to the unit just to look at its lines. When I told the Divisional Commander, General West, the other day that I was going to visit Col. Rangaraj, he warned me quickly: 'Be careful not to throw any matchsticks on the ground. That unit is the 'perfection of cleanliness'. Bearing in mind the Divisional Commander's warning I went along. $\mathrm{He}$ had not exaggerated. Everything was, in fact, spotless. Col. Rangaraj's only comment was : 'Have you ever seen a dirty hospital ? Of course not. Well, we like to think our camp can compare with any civilian hospital anywhere'.

And it certainly could.

\section{ADVANCED TRAINING IN U.K. FOR INDIAN DOCTORS}

Arrangements made under Colombo Plan

(Reproduced from Release No. B.F. 393, issued by the British Information Services, New Delhi)

IN response to a request from the Government of India, made under the Technical Co-operation Scheme of the Colombo Plan, for facilities for the training of Indian doctors in pædiatrics, the British Government 
have arranged for the training of three candidates, two of whom are already in the U.K.

Dr. (Miss) S. Damayanti, who is Assistant Medical Officer in the pædiatrics department of the Government General Hospital in Madras and tutor in pædiatrics at Madras Medical College, is at present taking a postgraduate course in pædiatrics at the Institute of Child Health of the Hospital for Sick Children, Great Ormond Street, London. She may go to Edinburgh at the end of this year to take the M.R.C.P. degree examination early in 1954 .

Dr. A. T. John, who is Doctor in Medicine and Assistant Physician at the Stanley Hdipital, . Madras, is also taking a six-month post-graduate course in pædiatrics at the Great Ormond Street Hospital.

The third candidate is Dr. Sohan Singh Manchanda, Medical Registrar and Resident Medical Officer at the V. J. Hospital, Amritsar, who is due to arrive in London later this month to take a post-graduate course for the M.R.C.P. degree, with pædiatrics as a special subject, under the Director of Studies, Edinburgh Fost-graduate Board of Medicine.

\section{British Postal Experts for India}

Two officers of the General Post Office in Britain, who are being seconded to the Government of India as a team of consultants to advise on the mechanisation of the Indian postal services, are now on their way to India in the liner Cilicia.

They are Mr. F. W. Guenier, who will act as postal adviser, and $\mathrm{Mr}$. P. E. C. Smith, who will be the technical consultant. The period of secondment, which has been arranged by the British Government under the Technical Co-operation Scheme of the Colombo Plan, will be nine months.

Mr. Guenier is an Assistant Postal Controller (Class 1) in the British G.P.O. Mr. Smith is an Asistant Staff Engineer in the P'ost Office Engineering Department.

\section{HEALTH SAFEGUARDS FOR THE MECCA PILGRIMS}

(Reproduced from W.H.O. News Letter, Vol. VI, No. 4, dated April 1953)

For the last seventy years the sanitary problems connected with the Mecca pilgrimage have been recognized as being of great international importance and several conventions have been drawn up to deal with them.

The latest measures are contained in an annex to the new international Sanitary Regulations, adopted unanimously by the Fourth World Health Assembly (Geneva, May 1951). They came into force on 1st October, 1952.

The Regulations are a standardization of the measures taken by the different countries at their frontiers against the danger of epidemics.

(They also forbid these countries to take excessive or arbitrary measures which might have harmful consequences for international travel and commerce.)

The part of the Regulations dealing with the Mecca pilgrimage is at the moment provisional.

A new sanitary station is almcst completed at Jeddah, on the Red Sea, facing Mecca, where the pilgrims will be examined. It will be put into operation for the pilgrimage season at the end of August this year. This station will replace that of Kamaran, now closed, and is being built with funds from Saudi Arabia, the help of the UN Technical Assistance Board and with the advice of the World Health Organization.

The station will be the first of its kind to be operated entirely under the control of the Saudi Arabian government.

The special regulations concerning the Mecca pilgrimage will cease to be applied as soon as Saudi Arabia has completed its health programme and established protective measures.

Since 1851, when the first international health conference was held in Paris, there has been a yearly improvement in the control measures adopted for the safety of pilgrims.

To-day each pilgrim is given a thorough physical examination before he leaves his country and before he sets foot on the soil of Arabia.

The efficiency of modern quarantine measures was well demonstrated in 1952 when the Health Administration of Saudi Arabia was able to announce that the pilgrimage of that year (the year 1371 by Mohammedan reckoning) was 'free from infection'.

\section{CONDITIONED AIR FOR CHILDREN'S HOSPITALS}

(Reproduced from a F'ress Release No. 113, dated 17th April, 1953, issued by Hungarian News and Information Service, 33, Pembridge Square, London, W2, Bayswater 6080 )

Budapest's No. 1 Children's Clinic is being fitted with apparatus which will guarantee constant atmospheric conditions in the wards whatever the weather may be like outside.

It is believed that by providing such conditions there is better chance for success for physicians and surgeons.

The apparatus supplies conditioned air at 75 degrees Fahrenheit and 70 per cent relative humidity, ultraviolet rays and ozone.

This material may be used in full or in part and it would be appreciated if cuttings or copies in which it is used are sent to the above address.

\section{DRUG RULES}

DRUGS RULES, 1945

(No. F.1-16/51-DS., Government of India, Ministry of Health, New Delhi-2, the 16th February, 1953)

\section{Notification}

THE following draft of certain further amendments in the Drugs Rules, 1945, which it is proposed to make in exercise of the powers conferred by sections 12 and 33 of the Drugs Act, 1940 (XXIII of 1940), is published as required by the said sections for the information of all persons likely to be affected thereby and notice is hereby given that the draft will be taken into consideration on or after the 21st May, 1953.

Any objection or suggestion which may be received from any person in respect of the said draft before 
the date specified will be considered by the Central Government.

In the said Rules-

\section{Draft Amendments}

1. In Schedule D, after item 5 , the following item shall be inserted, namely :- All the provisions

'6. The following substances which are used both as articles of food as well as drugs :-

(i) All condensed or powdered milk whether pure, skimmed or malted, fortified with vitamins and minerals or otherwise.

(ii) Farex, Oats, Lactose and all other similar cereal preparations whether fortified with vitamins or otherwise excepting those for parenteral use.

(iii) Virol, Bovril, Chicken essence and all other similar predigested foods.

(iv) Ginger, Pepper, Cumin, Cinnamon and all other similar spices and condiments unless they are specifically labelled as conforming to the standards in the British Pharmacopœia, British Pharmaceutical Codex, United States Pharmacopœia, National Formulary or Indian Pharmacopœial List.'

2. In Schedule $\mathrm{K}$, after item 8 , the following item shall be inserted, namely :-

'9. The following substances which are used both as articles of food as well as drugs :-

(i) All condensed or powdered milk whether pure, skimmed or malted, fortified with vitamins and minerals or otherwise.

(ii) Farex, Oats, Lactose and all other similar c e rea l preparations whether fortified with vitamins or otherwise excepting those for parenterals use.

(iii) Virol, Bovril, Chicken essence and all other simlilar predigested foods.

(iv) Ginger, P'epper, Cumin, Cinnamon and all other similar spices and condiments unless they are specifically labelled as conforming to the standards in the British

of Chapter III of the Act and Rules therenuder.
(No. F.10-21/49-D., Government of India, Ministry of Health, New Delhi-2, the 10th March, 1953)

\section{Notification}

IN exercise of the powers conferred by sections 12 and 33 of the Drugs Act, 1940 (XXIII of 1940), the Central Government hereby directs that the following further amendments shall be made in the Drugs Rules, 1945, the same having been previously published as required by the said sections, namely :-

A. In the said Rules,

(1) In sub-rule (2) of rule 59 for the word and figures ' Form 19 ', the words, figures and letter 'Form 19 or $19-\mathrm{A}$ ' shall be substituted;

(2) In rule $61-$

(a) In sub-rule (1) for the word and figures ' Form 20', the words, figures and letter 'Form 20 or $20-\mathrm{A}$ ' shall be substituted;

(b) In sub-rule (2) for the word and figures 'Form 21', the words, figures and letter 'Form 21 or $21-\mathrm{A}$ ' shall be substituted;

(3) To rule 62 , the following proviso shall be added, namely :-

'Provided that this shall not apply to itinerant vendors who have no specified place of business and who will be licensed to conduct business in a particular area within the jurisdiction of the licensing authority'.

(4) After rule 62 , the following rule shall be inserted, namely :-

'62-A. Restricted licences in Forms 20-A and 21-A'.

(a) Restricted licences in Forms 20-A and 21-A shall be issued, subject to the discretion of the licensing authority, to dealers or persons in respect of drugs whose sale does not require the supervision of a qualified person.

(b) Licences to itinerant vendors shall be issued only in exceptional circumstances for bona fide travelling agents of firms dealing in drugs or for a vendor who purchases drugs from licensed déaler for distribution in sparsely populated rural areas where other channels of distribution of drugs are not available.

(c) The licensing authority may issue a licence in Form 21-A to a travelling agent of a firm but to no other class of itinerant vendors for the specific purpose of distributing to medical practitioners or dealers samples of biological and other special products specified in Schedule $\mathrm{C}$ :

Provided that travelling agents of licensed manufacturers, agents of such manufacturers and of importers of drugs shall be exempted from taking out licence for the free distribution of samples of medicines among mem- 
bers of the medical profession, hospitals, dispensaries and the medical institutions or research institutions.

(5) In rule 65, for the words and figures 'Form 20 and Form 21', the words, figures and letters 'Form 20, 20-A, 21 and 21-A' shall be substituted.

B. In Schedule A to the said Rules, the following Forms shall be inserted after Forms 19,20 and 21 respectively, namely :-

\section{Form 19-A}

(See rule 59)

Application for a restricted licence to sell, stock and xhibit for sale and distribute drugs by itinerant vendors and other dealers who do not engage the services of a qualified person.

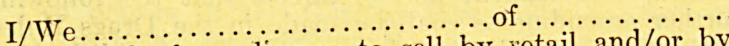
hereby apply for a licence to sell by retail and/or by wholesale drugs other than biological and other special products of the premises situated at.............
logical and other special products as vendor in the area.................

2 Sales shall be restricted to such drugs as can be sold without the supervision of a qualified person under the Drugs Rules.

3. Class of products to be sold.................

4. Particulars of the storage accommodation for the storage of biological and other special products on the premises referred to above....................

*5. The drugs for sale will be purchased from the following dealers and such other dealers as may be endorsed on the licence by the licensing authority from time to time.

Name of the dealer $(s)$

Licence No.

Date...............

Signature..............

* To be struck off if the applicant is not an itinerant vendor.

\section{Form 20-A}

[See rules $61(1)$ and $62-\mathrm{A}$ ]

Restricted licence to sell, stock and exhibit for sale and distribute drugs other than biological and other and distribute drugs for itinerant vendors and other dealers who do not engage the services of a qualified person.

. sell, stock, exhibit for sale and distribute on the premises situated at/at vendor in the area............ drugs other than biological and other special products specified in Schedule C to the Drugs Rules, 1945, subject to the conditions specified below and to the provisions of the Drugs Act, 1940, and the Rules made thereunder.

2. This licence will be in force for two years from the date given below.

3. The licensee can deal only in such drugs as can be sold without the supervision of a 'qualified person' under the Drugs Rules, 1945.

4. The licensee, if he be an itinerant vendor, shall buy drugs only from the following dealers and such other dealers as may be endorsed on the licence by the licensing authority from time to time.

\section{CONDITIONS OF LICENCE :}

1. This licence shall be displayed in a prominent and conspicuous place in a part of the premises open to be public or shall be kept on the person of the vendor who shall produce it on demand by an Inspector or an Officer authorized by the State Government in this behalf.

2. The licensee shall comply with the provisions of the Drugs Act, 1940, and the rules thereunder for the time being in force.

3. No drug in Schedule $\mathrm{C}(1)$ shall be sold unless the precautions necessary for preserving the properties of the contents have been observed throughout the period during which it has been in the possession of the licensee.

\section{Form 21-A}

[See rules $61(2)$ and $62-\mathrm{A}$ ]

Restricted licence to sell, stock and exhibit for sale and distribute biological and other special products specified in Schedule C, for itinerant vendors and deaers who do not engage the services of a qualified person,

. sell, stock, exhibit for sale and distribute on the premises situated at/as vendor in the area.......... the biological and other special products specified in Schedule C to the Drugs Rules, 1945, subject to the conditions specified below and to the provisions of the Drugs Act, 1940, and the Rules thereunder.

2. The licence will be in force for two years from the date given below.

3. Particulars of biological products to be sold......

4. The licensee can deal only in such drugs as can be sold without the supervision of a 'qualified person' under the Drugs Rules, 1945.

5. The licensee, if he be an itinerant vendor, shall buy drugs only from the following dealers and such other dealers as may be endorsed on the licence by the licensing authority from time to time.

Name of the dealer $(s)$.

Licence No.

Date............... Licensing Authority.

\section{CONDITIONS OF LICENCE :}

1. This licence shall be displayed in a prominent and conspicuous place in a part of the premises open to the public or shall be kept on the person of the vendor who shall produce it on demand by an Inspector or an Officer authorized by the State Government in this behalf.

2. No drug to which this licence applies shall be sold unless the precautions necessary for preserving the properties of the contents have been observed throughout the period during which it has been in the possession of the licensee.

(Sd.) S. DEVANATH, Under Secretary.

\section{ROYAL COLLEGE OF PHYSICIANS OF EDINBURGH}

At a Quarterly Meeting of College held on Tuesday, 3rd February, 1953, the Fresident, Dr. W..A. Alexander, in the chair, the following were elected Members of the College : 
D. G. McIntosh, м.в. (St. And.), D. G. C. Whyte, D.s.o., M.D. (Belf.), M. P. Goel, M.D. (Lucknow), L. S. C. Mendis, L.M.s. (Ceylon), G. M. Baird, м.в. (Edin.), B. Bevan, M.A. (Oxon.), B.M. (Oxfd.), D. P. Gupta, M.D. (Lucknow), J. B. Gibson, м.в. (Edin.), A. D. Muldoon, M.s. (N.U.I.), F. C. Friedlander, м.в. (Cape Town), L. Rabinowitz, м.в. (Cape Town), S. A. Syed, м.в. (Punjab), W. Frain-Bell M.D. (St. And.), J. Faul, ph.D. (Glas.), м.в. (Glas.), C. Marks, м.в. (Cape Town), F.R.c.s. (Eng.), C. H. Sivaraman, M.B. (Madras), E. M. McLachlan, м.в. (New Zealand), J. M. Neilson, M.B. (Glas.), R. H. Gosling, м.в. (Edin.), A. R. Somer, M.D. (Edin.), S. J. Cohen, м.в. (Witwatersand), D. H. H. Pullon, м.B. (New Zealand), M. Dan, м.в. (Cal.), Z. H. El Massry, м.в. (Cairo), S. Sing, м.в. (Cal.), J. A. Chunn, M.B. (New Zealand), J. L. Potter, м.в. (Edin), S. J. Irani, м.в. (Bom.), P. Sobti, в.sc. (Punjab), м.в. (Punjab).

\section{DR. M. G. CANDAU TAKES OVER AS NEW DIRECTOR-GENERAL OF WORLD HEALTH ORGANIZATION}

(Reproduced from a Press Release No. ROA/PR 021, issued by Pan American Sanitary Bureau, Regional Office of the World Health Organization, 1501, New Hampshire Avenue N.W., Washington 6, D.C., Hudson 3-5280)

Geneva, 15th May- $\mathrm{A}_{\mathrm{T}}$ the eighth plenary session of the World Health Assembly held in Geneva this morning, President Murched Khater administered the cath of office to Dr. M. G. Candau as Director-General of the World Health Organization as follows: "I solemnly swear to exercise in all loyalty, discretion, and conscience the functions entrusted to me as an international civil servant of the World Health Organization, to discharge those functions and regulate my conduct with the interests of the World Health Organization only in view, and not to seek or accept instructions in regard to the performance of my duties from any government or other authority external to the Organization.'

\section{ROYAL COLLEGE OF PHYSICIANS OF EDINBURGH}

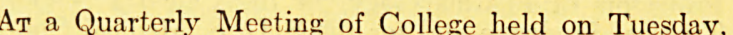
*5th May, 1953, the President, Dr. W. A. Alexander, in the chair, the following were elected Members of the College :

D. S. Nand, м.в. (Funjab), G. R. B. Kumarakulasinghe, L.M.S. (Ceylon), W. MacLeod, м.в. (Edin.), S. N. Wanchoo, м.в. (Punjab), L. K. Ganguli, B.sc. (Cal.), M.B. (Cal.), W. D. L. Fernando, L.M.s. (Ceylon), N. Y. McCallim, м.в. (Sydney), E. W. Moore, м.c., м.в. (Brist.), M. Hasan, M.D. (Punjab), R. A. Gulmohamed, M.в. (Bom.), I. F. Sutherland, M.в. (Edin.), D. A. I. Grewar, м.в. (St. And.), B. Senior, м.в. (Witwatersrand), Y. Ho, L.M.S. (Singapore), Q. G. Quah, L.M.s. (Singapore), S. K. Biswas, M.D. (Cal.), W. S. A. Allan, м.B. (Edin.), T. H. Maniar, M.D. (Bom.), K. Z. Hasan, м.в. (Osmania), M. M. Baig, m.B, (Osmania), W. L. F. Hatchuel, м.в. (Witwatersrand), A. Sandler, м.в. (Witwatersrand), I. N. Marks, B.sc. (Cape Town), м.в. (Cape Town), A. T. Lambie, м. B. (Edin.), J. K. McKechnie, в.sc. (Witwatersrand), м.в. (Witwatersrand), C. Nwokolo, L.R.C.P. (Lond.)

\section{College Library}

The College approved of regulations permitting suitably qualified persons to read in and borrow from the Library. The College Library, the use of which

* Published in a late issue.-EDrop, I.M.G. has hitherto been restricted to Fellows, was founded in 1681 and is the oldest medical library in Scotland. It is almost entirely restricted to medicine and contains nearly 200,000 volumes.

WORLD HEALTH ASSEMBLY COMMITTEE ADOPTS PROPOSAL EXTENDING REPRESENTATION OF NON-GOVERNMENTAL ORGANIZATIONS

(Reproduced from a Press Release No. ROA/PR 023, issued by Pan American Sanitary Bureau, Regional Office of the World Health Organization, 1501, New Hampshire Avenue, N.W., Washington 6, D.C., Hudson 3-5280)

Geneva, 18th May-THe Committee on Administration, Finance and Legal Matters of the Sixth World Health Assembly now meeting in Geneva, adopted a proposal to-day which would enable a 'plurality' of non-governmental organizations in the same health field to enter into official relationship with the World Health Organization. Under the present system only one non-governmental organization in any one field may be represented.

The proposal will be submitted to the full Assembly for final action.

The Committee also proposed that the Seventh World Health Assembly in 1954 be held in Geneva.

The Committee on Administration, Finance and Legal Matters is one of the two main committees through which the work of the World Health Assembly is carried on.

\section{A NEW FORTY-BED T.B. HOSPITAL AT JAMSHEDPUR}

The Ardeshir Dalal Tuberculosis Hospital at Jamshedpur was opened on 27th March by Dr. Srikrishna Sinha, Chief Minister of Bihar. The intention behind this institution is to provide not only the normal facilities of a T.B. Hospital but also occupational therapy for patients under treatment or while convalescing. The means for occupational therapy such as workshops and the like will also be utilized to enable the families of patients to maintain themselves while the patients are under treatment. Employees of the Tata Iron \& Steel Co. and associated concerns will be admitted to this hospital free from charge.

The equipment of the hospital, which is on the most modern lines, includes a small operation theatre and a Philips $500 \mathrm{~mA}$ X-ray apparatus with accessories for serial and layer radiography.

\section{WHO ASSISTANCE TO INDIA \\ World Health Day Round-úp}

(Reproduced from a Press Release No. SEA/PR/53-18, issued by World Health Organization, Regional Office for South-East Asia, New Delhi)

IN a review of World Health Organization activities in India issued by the WHO Regional Office for S.-E. Asia for World Health Day (7th April), it is stated that there are at present more WHO-assisted programmes in active operation in India than in any other single country. Out of a total of 200 health projects launched in 62 different countries with WHO assistance, eighteen are in India employing an international staff of 38 professors, doctors, nurses and technicians. 
Malaria-An anti-malaria campaign in the Terai of Uttar Pradesh has succeeded within three years in protecting a population of 200,000 living in 1,750 sq. miles, thus making. possible an influx of new colonists, an increase of 36,000 acres in the area under cultivation, and a leap in food production from 55,000 tons in 1947-48 to 73,500 tons in 1950-51. At the end of 1952 this project, launched in 1949 with assistance from WHO and UNICEF, was entirely taken over by the U.P. Government, and forms the starting point for a state-wide malaria control drive.

Similar projects assisted by WHO and UNICEF in two of India's worst malaria hot-beds in Orissa and South Malabar gave effective anti-malaria protection at a cost which worked out at between 8 and 12 annas per head of population. Both are now being carried on by the respective State Governments.

Anti-syphilis campaign.-A project-the first of its kind in India-for the control of venereal disease among a scattered rural population was established in 1949 by the Himachal Pradesh Government with an international team and laboratory and other equipment from WHO.

Laboratory diagnosis of blood samples from the population in certain parts of the area revealed that up to 60 per cent were positive for syphilis.*

In order to demonstrate the potency of penicillin in mass campaigns against syphilis, practically the total population was treated in one fairly isolated hill district. The records of the local dispensary showed that in the 12 months following the demonstration, only 12 new cases reported for treatment as against 68 in the six months preceding.

At the team's Simla headquarters more than $\mathbf{5 0}$ doctors and laboratory workers from all over S.-E. Asia were trained in the new methods of treatment and of laboratory diagnosis. As a result VD control on modern lines has now been established in more than 13 districts all over India with UNICEF help in laboratory supplies and equipment.

In 1952 a WHO doctor and public health nurse and a U.N. Technical Assistance social worker joined the staff of the V.D. Department of the Madras General Hospital to assist in developing an All-India training centre in modern methods of venereal disease control.

Yaws.-Yaws is a non-venereal disease resembling syphilis which cripples a large proportion of the population in areas where it is prevalent. Like syphilis it can be controlled by penicillin.

A WHO specialist is at present assisting the Madhya Pradesh Government with a pilot yaws control project in the eastern part of the State. His preliminary survey shows that the disease constitutes a serious problem throughout the area and probably also in the neighbouring States of Orissa and Hyderabad. UNICEF has agreed to assist in providing supplies and transport for the project.

Tuberculosis and BCG.-In 1952 a new tuberculosis centre in Patna was added to the two previously established in Delhi and Trivandrum with assistance from WHO and UNICEF. These centres provide training in modern methods of tuberculosis control suited to Indian conditions with emphasis on domiciliary treatment. They are obtaining, often for the first time, accurate information on the true seriousness of tuberculosis among different sectors of the population.

WHO and UNICEF are continuing their participation in mass BCG vaccination* campaigns carried on by national teams in a number of States. Up to present

* Final decision should be based on clinical findings, in view of new antigens and new workers.-EDror, I.M.G. a total of 14 million persons have been tested, and $4 \frac{1}{2}$ million of them who were found to need protection against tuberculosis have been vaccinated. Thirty-five doctors and 140 technicians have been trained in BCG vaccination techniques by the international staff.

Maternal and child health and nursing training.The maternal and child health project operating in Delhi State (Najafgarh) with assistance from WHO and UNICEF is continuing its regular training programme for nurses, midwives and health visitors. Refresher courses for health visitors and nurses were held in conjunction with various Delhi colleges and training institutions.

The first regular course for public health nurses ever held in India was organized recently at the Delhi Nursing College with WHO assistance.

During 1952 WHO has provided two nursing tutors for the Medical College Hospital, Calcutta, and a specialist in child nursing to the Madras General Hospital. Nursing training activities are being further extended in 1953 and 1954 .

Plague.-A WHO specialist was assigned to Uttar Pradesh in 1952 to help investigate the carry-over of plague infection and the persistence of outbreaks in certain localities of the State. Preliminary work is satisfactory, and far-reaching results are expected from this project.

Rabies.-Important advances in methods of diagnosing, treating and controlling rabies are being introduced in a number of countries as a result of an inter-regional rabies seminar held in Coonoor in July 1952 under WHO auspices.

Penicillin and DDT production.-To assist India on the road to self-sufficiency in the production of penicillin, specially important for controlling yaws and venereal disease, and DDT which is essential for the planned nation-wide expansion of malaria control, WHO and UNICEF are assisting the Indian Government in setting up a penicillin factory at Pimpri, near Poona and a DDT plant in Delhi. Both are expected to go into production in 1954 .

Medical education.-During 1952 WHO recruited a Principal for the Trivandrum Medical College; two Professors of Pharmacology for the Calcutta School of Tropical Medicine and for the S. G. S. Medical College, Bombay; a Professor of Industrial Hygiene for the All-India Institute of Hygiene and Public Health, Calcutta; and two physiotherapists for the K. E. M. Hospital, Bombay; where an All-India physiotherapy training centre is being developed.

Early in 1953 a team of 14 of the world's leading medical scientists spent four weeks each in Madras and Bombay and shorter periods in other medical centres under the auspices of WHO and the Unitarian Service Committee. At the end of the team's strenuous programme of lectures, clinical and technical discussions, and surgical and laboratory demonstrations, and seminars, members of the medical and allied professions in the centres visited were unanimous in declaring the project one of the most valuable that WHO had ever undertaken.

Fellowships.-In the last fifteen months, forty Indian doctors and health workers have been able to obtain advanced study in their special subjects through WHO Fellowships financed by WHO, UNICEF and U.N. Technical Assistance. The majority have been for study in tuberculosis and other communicable diseases, and a smaller number for nursing and other branches of medical science.

* For evidence against BCG. in editorial in this journal 


\section{ANCIENT FIND HELPS SCIENTISTS ON CORROSION PROBLEMS}

(Reproduced from UNESCO Features, No. 94)

IroN implements 2,000 years old, discovered recently near York in the north of England in a perfect state of preservation, may shed new light on the protection of metals from corrosion, according to the British periodical 'Discovery'.

Although the iron articles, ranging from hobnails to knives, had been buried in peaty, waterlogged soil, they showed on sign of rust. Samples of the soil were sent to a chemical research laboratory where analyiss showed traces of tennate. The area had been the centre of the leather industry in the Middle Ages and several old shoes and leather cuttings were found on the site.

Experiments have proved that a very small percentage of tannic acid in water impedes corrosion. The aiscovery may result in a method of protecting water and gas pipes and other metal objects. (UNESCO.)

\section{TELEVISION AND THE TEACHING OF MEDICINE}

THe University of Mexico is now using television in teaching the fundamentals of anatomy and physiology. Numerous technical difficulties have been overcome, notably in the lighting and colouring of specimens. Lectures are given to groups of 400 students using big screens, while more highly specialized instruction is given to smaller groups on sets of the usual size. (UNESCO.)

\section{NORWEGIAN CANCER HOSPITAL TO HAVE 31 MILLION VOLT BETATRON}

A 31 MLLION volt betatron for the treatment of internal tumours is being installed in a cancer hospital in Oslo. Designed by the Norwegian engineer Rolf Wilderöe, and built at Baden, Germany, the betatron is the most powerful apparatus thus far developed for the use of radiations in cancer treatment. Mr. Wilderöe calculates that 92 per cent of the radiations will penetrate to tumours ten centimetres (4 inches) under the surface of the skin. With earlier devices, 70 per cent of the radiations are lost. (UNESCO.)

\section{PAKISTAN GOVERNMENT AND WHO BUILD SOCIAL HYGIENE CENTRE IN KARACHI}

Construction of a centre for social hygiene, sponsored jointly by the Government of Pakistan and the World Health Organization, has just been completed at Karachi. The WHO is to supply medicines and such equipment as laboratory instruments, etc. (UNESCO.)

\section{INDIAN SPECIALIST STUDIES T.B. TREATMENT IN U.K.}

(Reproduced from a Release No. BF. 689, issued by British Information Services, Eastern House, Mansingh Road, New Delhi)

The Director of the Tuberculosis Demonstration and Training Centre, Patna, Dr. Bijoy Kumar Banerjee, is among a group of tuberculosis specialists now making a study of British practice in the prevention and treat- ment of the disease, as well as after-care and resettlement.

The fortnight's course, which ends on 25th April, has been arranged by the British Council in Birmingham and London. The nine doctors taking part, who come from India, Australia, Finland, Italy, Portugal and Switzerland, are mostly specialists in tuberculosis.

They have been attending lectures by leading British specialists dealing with such aspects of the disease as tuberculosis in industry, tuberculosis meningitis, nontuberculous chest conditions, and tuberculin testing in school-children. They are also visiting hospitals, clinics, research institutions, convalescent and resettlement centres, including the Papworth Village Settlement near Cambridge.

The course has been planned under the guidance of Dr. W. H. Wynn, consulting physician to the Queen Elizabeth Hospital, Birmingham, and Emeritus Professor of Medicine at Birmingham University, and Dr. C. H. C. Toussaint, consultant chest physician to the Willesden Chest Clinic and to the Central Middlesex Hospital.

23-4-53.

\section{ADVANCED STUDIES- UNDER COLOMBO PLAN More Indian Trainees Reach U.K.}

(Reroduced from a Release No. BF. 714, issued by British Information Services, Eastern House, Mansingh Road, New Delhi)

Two more Indians have just started studies in Britain under the Technical Co-operation Scheme of the Colombo Plan. They are Dr. H. I. Jhala, Professor of Pathology at the Grant Medical College, Bombay, and Mr. Das Gupta, Agricultural Engineer to the Government of Rajasthan.

Dr. Jhala, in Britain for a year, will for the first six months be at the Post-Graduate Medical School in Hammersmith, London, working as a visiting colleague with Professor J. H. Dible. During the second half of his stay, two months will be spent at Cambridge, one at Edinburgh, and three months visiting pathological laboratories in various parts of the country.

Mr. Das Gupta is undertaking a four-month course in the practical aspects of farm mechanisation with a leading British tractor manufacturing firm. This represents the U.K. Government's response to a request from the Government of India, which sought facilities for advanced training in the mechanisation of agriculture. The facilities were required for an agricultural engineer who will be employed on the introduction of mechanical farming schemes in Rajasthan, under the Indian Government's Five-Year Plan.

Mr. Das Gupta is taking his training in the tractor firm's education department at Stoneleigh Abbey at Kenilworth, Warwickshire. Mr. Das Gupta, who qualified as a mechanical engineer from the Jadavpur College of Engineering and Technology, was at one time employed as a drilling instructor in the construction of tube-wells. Later he was employed by the Central Water and Power Commission of the Government of India.

Other Colombo Plan trainees from India who have reached Britain this month include Mr. V. S. Gupta, Chief Electrical Engineer, Indian State Railways, and Mr. K. I. Mani, Assistant Electrical Engineer (Construction), Public Works Department, Madras, who are both undertaking specialized practical training in power engineering; and Mr. S. Roy, Assistant Labour Commissioner, Government of West Bengal, who is taking a four-month course on labour statistics with the British Ministry of Labour.

25-4-53. 


\section{NEW ROYAL YACHT LAUNCHED}

(Reproduced from a Release No. BF. 656, issued by British Information Services, Eastern House, Mansingh Road, New Delhi)

The new Royal yacht was launched at a Clydebank yard, on 16th April by H.M. Queen Elizabeth, who named it 'Britannia'.

The yacht has been so designed that, if ever occasion required, it could be transferred into a hospital ship. The Royal and State apartments are suitable for conversion into hospital wards and operating theatres.

Launching the yacht, the Queen spoke of the Britannia 'not only as the most modern addition to a long line of Royal yachts which goes back to the reign of King Charles II', but as the ship which 'is to be at times the home of my husband and myself and of our family?

17-4-53.

\section{TO BE PUBLISHED IN PART II SECTION 3 OF THE GAZETTE OF INDIA, DATED 4 TH APRIL 1958}

(No. F.1-19/50-DS., Government of India, Ministry of Health, New Delhi-2, dated 30th March, 1953) Notification

IN exercise of the powers conferred by sections 12 and 33 of the Drugs Act, 1940 (XXIII of 1940), the Central Government hereby directs that the following further amendment shall be made in the Drugs Rules, 1945 , the same having been previously published as required by the said sections, namely :-

In Schedule $K$ to the said Rules, after item 8, the following item shall be added at the end, namely :-

The provisions of Sub-clause $(i)$ of clause $(a)$ of section 18 of the Act to the following extent :Chlorides present in the salt shall not exceed 0.12 per cent

'9. Magnesium Sulphate.

To

The Publisher Gazette of India, NEW DELHI.

\section{Current Topics, Etc.}

\section{Serological Test for Syphilis False Positive Reactions in Leprosy}

By N. P. GUPTA et al.

(Abstracted from the Indian Journal of Medical Sciences, Vol. 7, January 1953, p. 23)

A TOTAL number of 263 sera from clinically nonsyphilitic cases of lepromatous and tuberculoid types of leprosy have been serologically studied.

All the samples were tested with W.R., Kahn test and Meinicke and V.D.R.L. tests. All the four tests were found to give false positive S.T.S. with sera from cases of leprosy to a variable extent.

The incidence of false positive S.T.S. has been fairly high in W.R. and V.D.R.L. tests. Meinicke reaction gave rise to much fewer false positive S.T.S. than any of other tests used.
Incidence of false positive S.T.S. was found to be greater in lepromatous cases than in tuberculoid type of leprosy.

Selected positive sera were titrated and it was found that the titres of false positive sera ran fairly high.

Forty-three out of 50 sera giving a false positive S.T.S. became negative after sera had been heated to $65^{\circ} \mathrm{C}$. for 4 minutes while six sera from known syphilitic cases persistently showed positive reactions after being treated in the same manner.

Duration and the type of treatment was not found to have any effect on serological reactions.

\section{Treatment of Ascariasis in Children with Hetrazan Syrup}

\author{
By M. T. HOEKENGA
}

(Abstracted from the American Journal of Tropical Medicine and Hygiene, Vol. 1, July 1952, p. 688)

ONE HUNDRED and twenty-five Honduran children were treated for ascariasis with 1-diethylcarbamyl-4methylpiperazine hydrochloride (Hetrazan) in a syrup which contained $30 \mathrm{mg}$. of the drug per cc. Of the dosages employed, the most effective was $12 \mathrm{mg}$. per pound of body weight daily for 4 days; in 80 per cent of 30 cases this amount resulted in absence of ascaris eggs from concentrated (zinc sulphate flotation) stools on both of two post-treatment examinations. Smaller* amounts gave less satisfactory results. Eighteen mg. per pound of body weight appeared to be too toxic.

Factors effecting the apparent cure rate are discussed. The most important are the criteria of cure and the season of the year during which the study is done.

It is concluded that when it is undesirable to fast or purge, diethylcarbamazine may be a satisfactory vermifuge. It should be of particular advantage in private practice. However, it is not an ideal compound for mass treatment because multiple doses are necessary.

\section{Fumagillin in Amoebiasis}

By H. H. ANDERSON et al.

(Abstracted from the American Journal of Tropical Medicine and Hygiene, Vol. 1, July 1952, p. 552)

Fumagillin was isolated from Aspergillus fumigatus (NNRL 171) by Hanson and Eble. It was first described as an antiphage agent. While the chemical composition is not known, it does occur in crystals and has been reported to contain only carbon, hydrogen and oxygen. This antibiotic has shown slight antibacterial or antifungal activity. Its chief attribute as a direct acting amœbicide was demonstrated by McCowen, Callender and Lawlis. Against Endamœba histolytica in vitro, fumagillin was reported active at one to four million in the absence of multiplying bacteria associates. In the presence of Trypanosoma cruzi, the associates. levels was found by Hrenoff and Nakamura to be from one to ten to 15 million dilution. 'I he trypanosomes were not affected by these concentrations. Against experimentally induced rat and rabbit infection with $E$. histolytica, total doses of $11 \mathrm{mg}$. per kilo orally in rabbits over two days proved to be amœbicidal on the basis of these initial observations it was believed desirable to study fumagillin in chronic amœbiasis of macaques and man.

Fumagillin, orally, is active directly against $E$. histolytica of macaques and man. In man, at a total dosage 